\title{
Ventricular parasystole in acute myocardial infarction
}

\author{
J. Salazar ${ }^{1}$ and C. S. McKendrick \\ From the Liverpool Cardiac Centre, Sefton General Hospital, Smithdown Road, Liverpool I5
}

The clinical and electrocardiographic features of II patients with ventricular parasystole in acute myocardial infarction are described. This arrhythmia always appeared within the first 24 hours after the beginning of the pain, and lasted usually a few hours. Only one patient received digitalis before the appearance of the arrhythmia; the others did not receive any drug of known arrhythmic potential. The treatment was mainly with lignocaine intravenously, the response to which was usually very good.

There was no relation between this arrhythmia and the plasma potassium levels.

The electrocardiographic finding of fusion beats, coupling, retrograde conduction, interectopic interval, ectopic cycle length, and exit block were analysed. Two of the cases were examples of intermittent parasystole.

The relation between this arrhythmia and the slow idioventricular rhythm was discussed.

It appears that this is a benign arrhythmia, easily controlled by treatment, produced perhaps by the same mechanisms as ventricular tachycardia, but with the existence of exit block.

Parasystole is a rare arrhythmia in which an automatic ectopic centre, usually situated in the ventricles, forms rhythmic stimuli without being disturbed by the sinus rhythm. These stimuli produce a ventricular contraction whenever they arise outside the refractory phase of the ventricles (Scherf and Boyd, 1950). Because of interference between sinus and automatic rhythms, some automatic stimuli are formed just when a sinus stimulus spreads over the ventricles. In this instance, one part of the ventricles will be activated by the sinus stimulus and another by the automatic stimulus. In this way, fusion beats appear in the electrocardiogram (Malinow and Langendorf, 1948; Marriott, Schwartz, and Bix, 1962). Normally the excitation wave spreading over the heart depolarizes every cell and prevents all potential centres from forming stimuli; the so-called secondary centres in the atrioventricular node and the tertiary centres in the ventricles are silenced. In this special situation of ventricular parasystole, the centre in the ventricle wall is not disturbed by the conducted stimulus (Scherf and Chick, I95I).

Typically, ventricular parasystole is manifested in the electrocardiogram by the apReceived 17 November 1969.

${ }^{1}$ Present address : Fundacion Jimenez Diaz, Departamento de Cardiologia, Madrid. pearance of ventricular premature beats. Contrary to the common variety of premature beats, their coupling with the preceding sinus beats varies widely (Scherf, Blumenfeld, and Yildiz, 1962). The presence of an autonomous ectopic rhythm, different in rate from that of the dominant pacemaker, must be demonstrated. This is done when the intervals separating ectopic beats can be reduced to a least common denominator corresponding to the cycle length of the parasystolic ectopic rhythm (Pick, 1953). The three cardinal signs of parasystole are: (I) presence of variable coupling; (2) presence of fusion beats; and ( 3 ) the periods free from ectopic beats, which are filled by sinus beats, have the length of a simple multiple of one ectopic cycle length (Scherf and Chick, I95I ; Surawicz and MacDonald, 1964; Schamroth, 1962; East and Bain, 1959).

The mechanism by which one rhythmic centre is protected from the impulses of others has been a matter of speculation. The idea of an area of unidirectional block surrounding an ectopic focus has been proposed (Katz, 1946; Vedoya and Rodriguez Battini, 1939). Experiments in animals show that a rapidly firing centre is protected from the normal impulses which spread over the heart, and, thus, the hypothesis of entrance (protection) block is not necessary (Scherf 
et al., 1962; Scherf and Chick, 1951). The inference that different degrees of exit block have been proved in most cases of parasystole obviates the necessity of postulating the presence of a protection block (Schamroth, 1962; Scherf and Bornemann, 196I; Rossi, Motolese, and Passaro, 1959). The slow manifest ectopic rate seen in most of the cases is explicable on the basis of a relatively fast ectopic rhythm, discharging with a high grade of exit block. Momentary dissipation of the exit block, even if only for one beat, results in $I: I$ conduction, thereby revealing the ectopic cycle length (Schamroth, 1962). The exit block is usually $2: 1$ but may occasionally be $3: 1$ or even $4: 1$. The degree of exit block may also fluctuate in the same recording.

So, if a centre fires off impulses rapidly it will be refractory to other impulses. We have no way of knowing whether or not an apparently slow parasystolic focus is the expression of a more or less high grade of exit block of one centre firing at a really high speed. Thus, in explaining parasystole, recourse need not be taken to theories which contradict known physiological laws (Scherf and Bornemann, 196I).

The purpose of this paper is to report the clinical and electrocardiographic findings in II patients with ventricular parasystole in acute myocardial infarction.

\section{Subjects and methods}

The Intensive Coronary Care Unit was opened in June 1965, with two beds; this was increased to six beds in September I968. From the time when the Unit was opened until January 1969, 700 patients were admitted. In 90 per cent the diagnosis of myocardial infarction was confirmed by the electrocardiographic abnormalities and laboratory results.

As soon as the patients arrived at the Unit, a catheter for central venous pressure was inserted in the right atrium (via basilic vein by percutaneous puncture or cut-down), and the patient was continuously monitored (a bed-side oscilloscope and an oscilloscope in a central control for nurses and doctors). Provided there were no complications, the patients remained in the Unit for 3 days. If there were any complications, the patient remained until these had disappeared, or, in the case of arrhythmias, 12 to 24 hours after the last arrhythmia had ceased. In all these patients an electrocardiogram was taken hourly from a central electrocardiographic recorder (Elema-Schonander, 7 channels; ECG recorder Devices 2 channels). In addition, when an arrhythmia appeared on the monitor, another electrocardiogram was recorded. A complete electrocardiogram (I2 leads) was recorded daily.

Serum aspartate aminotransferase estimations were done the first three days, as well as other laboratory routine examinations (electrolytes, blood gases, white blood count, etc.).

All the electrocardiographic tracings of patients with ventricular extrasystoles were analysed carefully, and II patients were found to have ventricular parasystole. A clinical history of myocardial infarction with late confirmation by electrocardiographic changes and laboratory results were present in all of them. Case 5 was in the Unit for 12 days, Cases 7 and ro were in for 4 days, and the other 8 cases were in for 3 days. After being in the Unit, the patients were transferred to an ordinary ward, and the time in hospital was about 4 weeks.

\section{Results}

Clinical findings (Table I) Ventricular parasystole was found in II ( 9 men, 2 women) out of 630 patients with acute myocardial infarction, an incidence of $\mathrm{I} \cdot 7$ per cent. The ages of the patients ranged from 47 to 67 years, the average age being 60 years. In 9 this was the first myocardial infarction, and in 2 it was the second. The sites of infarctions were as follows: anterior in 6, anteroseptal in 4 ( 2 of them with an old posterior), and posterior in I. The time of appearance of the arrhythmia calculated since the beginning of the chest pain varied between 3 and 24 hours, with an average value of approximately ro hours. The duration of the arrhythmia varied from I hour to Io days, with an average of approximately 49 hours.

Only one patient received digitalis before the appearance of the arrhythmia. The rest of them did not receive any drug of known arrhythmic potential, and only analgesics to relieve the pain (morphine or heroin). The patient who received digitalis had the longest duration of parasystole (IO days).

To treat parasystole, lignocaine was administered to 7 patients $(50 \mathrm{mg}$. stat. intravenously followed by $\mathrm{I}-2 \mathrm{mg}$. $/ \mathrm{min}$. intravenous infusion), procainamide to 2 patients (500 mg. 6-8 hourly orally), lignocaine and procainamide to I patient, and atropine to I patient $(0.6 \mathrm{mg}$. subcutaneous injection 6 hourly). Lignocaine produced no sideeffects in these patients.

Before the appearance of ventricular parasystole, 3 patients were in normal sinus rhythm, 7 were in sinus tachycardia, and one was in sinus bradycardia. After ventricular parasystole disappeared 9 patients were in normal sinus rhythm, one was in sinus tachycardia, and another (Case I) had a transient episode of atrial fibrillation lasting for about 4 hours, which reverted to sinus rhythm with digitalis; this atrial fibrillation appeared 12 hours after the ventricular parasystole had disappeared. 
TABLE I Clinical findings in II patients with ventricular parasystole in acute myocardial infarction

\begin{tabular}{|c|c|c|c|c|c|c|c|c|c|c|c|c|c|c|}
\hline \multirow{2}{*}{$\begin{array}{l}\text { Case } \\
\text { No. }\end{array}$} & \multirow{2}{*}{$\begin{array}{l}\text { Age } \\
(y r .)\end{array}$} & \multirow{2}{*}{ Sex } & \multicolumn{2}{|c|}{ Localization of infarct } & \multirow{2}{*}{$\begin{array}{l}\text { Para- } \\
\text { systole } \\
\text { delay } \\
\text { since } \\
\text { pain } \\
(\text { hr. })^{\star}\end{array}$} & \multirow{2}{*}{$\begin{array}{l}\text { Para- } \\
\text { systole } \\
\text { duration } \\
(\text { hr. })^{\star}\end{array}$} & \multirow{2}{*}{$\begin{array}{l}\text { Drugs } \\
\text { given } \\
\text { before } \\
\text { para- } \\
\text { systole }\end{array}$} & \multirow{2}{*}{$\begin{array}{l}\text { Drugs } \\
\text { given to } \\
\text { treat para- } \\
\text { systole }\end{array}$} & \multicolumn{2}{|l|}{ Arrhythmias } & \multicolumn{2}{|c|}{$\begin{array}{l}\text { Plasma potassium } \\
(m E q / l .)\end{array}$} & \multirow{2}{*}{$\begin{array}{l}\text { SGOT } \\
\text { (units/ } \\
\text { roo ml.) } \\
\text { higher } \\
\text { values }\end{array}$} & \multirow{2}{*}{$\begin{array}{l}\text { Follow- } \\
\text { upt }\end{array}$} \\
\hline & & & Acute & Old & & & & & $\begin{array}{l}\text { Before para- } \\
\text { systole }\end{array}$ & $\begin{array}{l}\text { After para- } \\
\text { systole }\end{array}$ & $\begin{array}{l}\text { During } \\
\text { para- } \\
\text { systole }\end{array}$ & $\begin{array}{l}\text { After } \\
\text { para- } \\
\text { systole }\end{array}$ & & \\
\hline $\mathbf{I}$ & 60 & $\mathbf{M}$ & $\begin{array}{l}\text { Antero- } \\
\text { septal }\end{array}$ & Posterior & 5 & 5 & & Lignocaine & $\begin{array}{l}\text { Sinus } \\
\text { tachy- } \\
\text { cardia }\end{array}$ & $\begin{array}{l}\text { Atrial } \\
\text { fibrilla- } \\
\text { ion }\end{array}$ & $4 \cdot 8$ & & 510 & Recovery \\
\hline 2 & 55 & $\mathbf{F}$ & Anterior & & 15 & $\mathbf{I}$ & & Lignocaine & $\begin{array}{l}\text { Sinus } \\
\text { tachy- } \\
\text { cardia }\end{array}$ & $\begin{array}{l}\text { Sinus } \\
\text { tachy- } \\
\text { cardia }\end{array}$ & 3.9 & & 240 & Recovery \\
\hline $\begin{array}{l}3 \\
4\end{array}$ & $\begin{array}{l}61 \\
63\end{array}$ & $\begin{array}{l}\mathbf{M} \\
\mathbf{M}\end{array}$ & $\begin{array}{l}\text { Posterior } \\
\text { Anterior }\end{array}$ & & $\begin{array}{r}\text { Io } \\
7\end{array}$ & $\begin{array}{r}4 \\
60\end{array}$ & & $\begin{array}{l}\text { Lignocaine } \\
\text { Procain- } \\
\text { amide }\end{array}$ & $\begin{array}{l}\text { Sinus } \\
\text { tachy- } \\
\text { cardia }\end{array}$ & & $\begin{array}{l}2 \cdot 6 \\
3 \cdot 9\end{array}$ & $\begin{array}{l}3 \cdot 3 \\
4 \cdot 1\end{array}$ & $\begin{array}{r}354 \\
80\end{array}$ & $\begin{array}{l}\text { Recovery } \\
\text { Recovery }\end{array}$ \\
\hline 5 & 53 & $\mathbf{M}$ & Anterior & & 24 & 240 & Digitalis & $\begin{array}{l}\text { Procain- } \\
\text { amide }\end{array}$ & & & $3 \cdot 9$ & & 325 & Recovery \\
\hline 6 & 67 & $\mathbf{F}$ & $\begin{array}{l}\text { Antero- } \\
\text { septal }\end{array}$ & & 5 & 16 & & Lignocaine & $\begin{array}{l}\text { Sinus } \\
\text { tachy- } \\
\text { cardia }\end{array}$ & & $4 \cdot 7$ & & Iso & Recovery \\
\hline 7 & 47 & $\mathbf{M}$ & Anterior & & 12 & 72 & & Atropine & $\begin{array}{l}\text { Sinus } \\
\text { brady- } \\
\text { cardia }\end{array}$ & & $3 \cdot 6$ & $3 \cdot 8$ & 120 & Recovery \\
\hline 8 & 66 & $\mathbf{M}$ & Anterior & & 4 & 40 & & Lignocaine & & & $5 \cdot 7$ & & 205 & Recovery \\
\hline 9 & 67 & $\mathbf{M}$ & $\begin{array}{l}\text { Antero- } \\
\text { septal }\end{array}$ & Posterior & 7 & 17 & & Lignocaine & $\begin{array}{l}\text { Sinus } \\
\text { tachy- } \\
\text { cardia }\end{array}$ & & $3 \cdot 8$ & $4 \cdot 2$ & 125 & Recovery \\
\hline 10 & 65 & $\mathbf{M}$ & $\begin{array}{l}\text { Antero- } \\
\text { septal }\end{array}$ & & 3 & 84 & & $\begin{array}{l}\text { Lignocaine, } \\
\text { procain- } \\
\text { amide }\end{array}$ & $\begin{array}{l}\text { Sinus } \\
\text { tachy- } \\
\text { cardia }\end{array}$ & & $4 \cdot 1$ & & 100 & Recovery \\
\hline I I & 57 & $\mathbf{M}$ & Anterior & & 24 & 3 & & Lignocaine & $\begin{array}{c}\text { Sinus } \\
\text { tachy- } \\
\text { cardia }\end{array}$ & & $5 \cdot 2$ & & 500 & Recovery \\
\hline
\end{tabular}

* Approximate values.

† During stay in hospital (average 4 weeks).

TABLE 2 Electrocardiographic findings in II patients with ventricular parasystole in acute myocardial infarction

\begin{tabular}{|c|c|c|c|c|c|c|c|c|c|c|c|c|c|c|c|}
\hline \multirow{2}{*}{$\begin{array}{l}\text { Case } \\
\text { No. }\end{array}$} & \multicolumn{4}{|c|}{ Sinus beats } & \multicolumn{2}{|c|}{ Fusion beats } & \multicolumn{9}{|c|}{ Parasystolic beats } \\
\hline & $\begin{array}{l}\text { Ratel } \\
\text { min. }\end{array}$ & $\begin{array}{l}\text { PR } \\
\text { inter- } \\
\text { ical }\end{array}$ & $\begin{array}{l}\text { QRS } \\
\text { dura- } \\
\text { tion }\end{array}$ & $\begin{array}{l}Q T \\
\text { inter- } \\
\text { val }\end{array}$ & Present & $\begin{array}{l}\text { PF } \\
\text { interval } \\
\text { (shor- } \\
\text { ter one) }\end{array}$ & $\begin{array}{l}\text { Vari- } \\
\text { able } \\
\text { coup- } \\
\text { ling } \\
(>8)\end{array}$ & $\begin{array}{l}\text { Shorter } \\
\text { coupling }\end{array}$ & $\begin{array}{l}\text { QRS } \\
\text { dura- } \\
\text { tion }\end{array}$ & $\begin{array}{l}\text { Retro- } \\
\text { grade } \\
\text { conduc- } \\
\text { tion }\end{array}$ & $\begin{array}{l}\text { Inter- } \\
\text { ectopic } \\
\text { interval } \\
\text { (shorter } \\
\text { one) }\end{array}$ & $\begin{array}{l}\text { Manifest } \\
\text { ectopic } \\
\text { discharge } \\
\text { rate/min. }\end{array}$ & $\begin{array}{l}\text { Ectopic } \\
\text { cycle } \\
\text { length } \\
\text { (medium } \\
\text { values) }\end{array}$ & Exit block & $\begin{array}{l}\text { Significant } \\
\text { variation } \\
\text { in manifest } \\
\text { cycle }\end{array}$ \\
\hline $\mathbf{I}$ & 94 & 16 & 12 & 32 & + & 18 & + & 44 & 12 & - & $\begin{array}{l}144 \\
(48 \times 3)\end{array}$ & 130 & 47 & $\begin{array}{l}3: 1 \\
4: 1\end{array}$ & - \\
\hline 2 & 133 & 16 & 8 & 30 & + & 20 & + & 32 & 16 & - & 139 & 44 & - & $2: 1 ?$ & + \\
\hline 3 & 79 & 14 & 8 & 40 & + & 20 & - & 60 & 14 & 一 & $\begin{array}{l}122 \\
(6 I \times 2)\end{array}$ & 112 & 58 & $\begin{array}{l}\text { Intermittent } \\
\text { farasys- } \\
\text { tole }\end{array}$ & - \\
\hline 4 & 110 & 20 & 10 & 36 & + & 24 & + & 48 & 16 & 一 & $\begin{array}{l}112 \\
(56 \times 2 .)\end{array}$ & 112 & 57 & - & - \\
\hline 5 & 80 & 12 & 8 & 34 & 一 & - & - & 40 & 16 & - & $\begin{array}{l}148 \\
(37 \times 4)\end{array}$ & 174 & 36 & $\begin{array}{l}\text { Intermittent } \\
\text { fara- } \\
\text { systole }\end{array}$ & - \\
\hline 6 & 84 & 16 & 8 & 40 & + & 20 & + & 52 & 14 & - & $\begin{array}{l}130 \\
(65 \times 2)\end{array}$ & 92 & 66 & - & - \\
\hline 7 & 50 & 18 & 8 & 42 & + & 20 & + & 60 & 12 & - & $\begin{array}{l}248 \\
(124 \times 2)\end{array}$ & 49 & 124 & - & - \\
\hline 8 & 63 & 18 & 8 & 36 & + & 20 & + & 52 & 12 & - & $\begin{array}{l}258 \\
(86 \times 3)\end{array}$ & 76 & 85 & - & - \\
\hline 9 & 107 & 14 & 12 & 36 & + & 16 & + & 40 & 12 & - & $\begin{array}{l}\text { IIO } \\
(55 \times 2)\end{array}$ & Iro & 55 & $2: 1$ & - \\
\hline ro & 90 & 16 & 10 & 34 & + & 20 & + & 44 & 12 & - & 116 & 47 & - & - & - \\
\hline II & 90 & I6 & 8 & 36 & + & 20 & + & 68 & 12 & - & $\begin{array}{l}141 \\
(70.5 \times 2)\end{array}$ & 86 & 70 & - & - \\
\hline
\end{tabular}

All time intervals are noted in hundredths of a second, i.e. 66 represents 0.66 sec. 
Only one patient (Case 3) had low plasma potassium levels during ventricular parasystole, and these low levels remained after this arrhythmia disappeared (we consider the normal lower plasma potassium values to be $3.5 \mathrm{mEq} / \mathrm{litre}$ ).

All the patients recovered during the period in hospital.

\section{Electrocardiographic findings (Table 2)} Sinus beats

The rate per minute varied between 50 and 133. Seven patients had sinus tachycardia, one had sinus bradycardia, and three had normal sinus rate (between 60 and 80 beats per minute). The PR interval was normal in all of them oscillating between 0.12 and 0.20 sec. The QRS duration was $0.08 \mathrm{sec}$. in 7 patients, 0.10 sec. in 2 , and $0.12 \mathrm{sec}$. in 2 (right bundle-branch block in these 2 patients, with acute antero-septal infarction (Fig. I and 5)). The QT interval oscillated between 0.30 and $0.42 \mathrm{sec}$.

\section{Fusion beats}

The presence of fusion beats is undeniably helpful in drawing attention to the possibility of parasystole, because they indicate an ectopic ventricular discharge that is not coupled to the preceding beat. The criteria followed for the diagnosis of ventricular fusion beats was that described by Marriott et al. (1962). Fusion beats were present in ro cases. They were absent in one patient (Case 5) with intermittent parasystole (see Fig. 4). The PJ interval varied from 0.16 to $0.24 \mathrm{sec}$.; in all of these the shorter PJ interval measured was never shorter than the PR interval of the sinus beat, an important point in the diagnosis of ventricular fusion beats (Marriott et al., 1962).

\section{Parasystolic beats}

Variable coupling (more than $0.08 \mathrm{sec}$.) was found in 9 patients. Two patients with fixed coupling corresponded to 2 with intermittent parasystole, where the first parasystolic beat was always coupled to the preceding sinus beat (Fig. 3 and 4). The shorter coupling varied between 0.32 and $0.68 \mathrm{sec}$. The shorter coupling was always longer than the QT interval. The longer coupling was present in Case 3 ( $0.60 \mathrm{sec}$.; a case of intermittent parasystole (Fig. 3)), and Cases 7 and II (0.60 sec. and 0.68 sec., respectively); in these 2 patients, the rates of the sinus node and of the parasystolic focus were close (see Fig. 6). The $\mathrm{QRS}$ duration was always 0.12 sec. or

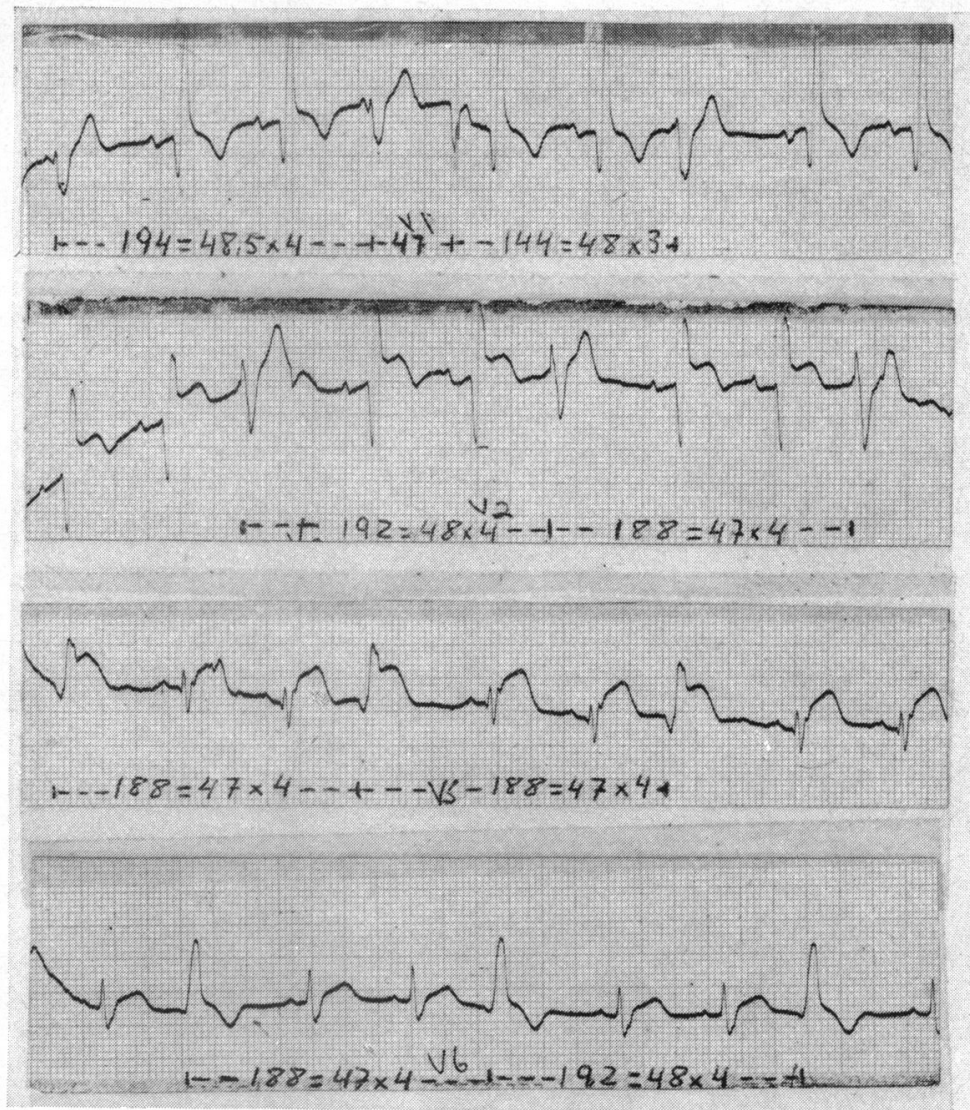

FIG. I Case I. Parasystolic focus firing at I30 a minute with 4: I exit block. Exit block suddenly disappears in lead VI. Sinus beat shows $R B B B$ pattern, and parasystolic beat shows $L B B B$ pattern.

more ( $0.12 \mathrm{sec}$. in 6 cases, $0.14 \mathrm{sec}$. in 2 cases, and $0.16 \mathrm{sec}$. in 3 cases), as was expected with beats proceeding from a ventricular focus.

No patient had electrocardiographic evidence of retrograde conduction of the ventricular impulses to the atria; sometimes it is impossible to prove this without an oesophageal lead (Kistin, I966). In Case 5 (Fig. 4), retrograde activation of the atria occurred, and temporarily depressed the discharge rate of the sinus node (concealed conduction).

The interectopic interval, defined as the interval between two ectopic beats containing an intervening sinus beat (Schamroth, 1962), was measured in all the patients. In Table 2 we can see the shorter interectopic interval of each patient, and it was a very close multiple of the ectopic cycle length in all the patients in whom the ectopic cycle length was manifest. The ectopic cycle length, the interval between two ectopic beats without inter- 
vening sinus beats, was seen in 9 patients, and oscillated between 0.36 and $I \cdot 24$ sec., with an average value of approximately $0.66 \mathrm{sec}$. The manifest ectopic discharge rate is represented by the shortest measurable interval between ectopic beats (Schamroth, 1962). It was more than 110 beats a minute in 5 patients (between $\mathrm{I}$ ro and $\mathrm{I} 74$ beats a minute), between 70 and 100 in 3 patients, and less than 50 beats a minute in 3 patients ( 2 of these without manifest ectopic cycle length).

Two of the patients (Cases 3 and 5) had intermittent parasystole. In another 2 (Cases I and 9) exit block was shown. In Case 2 (Fig. 2), the only case in which significant variation in the manifest cycle length occurred, a 2:I exit block was very likely (see Discussion).

\section{Discussion}

Two rhythmic and completely independent pacemakers operating at different rates can be seen to be in competition for the activation of the ventricles or of the atria. Such a condition is termed parasystole (Pick, 1953). In ventricular parasystole, one of the pacemakers is situated in the ventricles, below the bifurcation of the bundle of His, and the other one is usually the sinus node. Parasystole is found in 0.04 per cent of routine electrocardiograms obtained in a general hospital (Scherf and Boyd, 1950). Katz and Pick (1956) found 153 instances among 50,000 cases, that is an incidence of 0.3 per cent. The incidence of $1 \cdot 7$ per cent in these patients with acute myocardial infarction is far more frequent than that found in routine electrocardiographic examination. Though ventricular parasystole has occasionally been described in normal people (Heinz and Eldridge, 1957), it is usually associated with organic heart disease (Schamroth, 1962). In 49 cases reported by Scherf and Schott (I953), 38 had evidence of pronounced cardiovascular disease. Double ventricular parasystole has been described in patients with serious heart disease (Chung, Walsh, and Massie, 1964), but none was found in this series.

This arrhythmia usually appeared during the first few hours after the start of the pain (average ro hours), and always within the first 24 hours. Seven patients were treated with lignocaine, 2 with procainamide, I had a combination of both drugs, and I with sinus bradycardia had atropine. The response to treatment was apparently good; the arrhythmia was controlled in 6 patients within 17 hours, in 3 within 3 days, in I in $3 \frac{1}{2}$ days, and

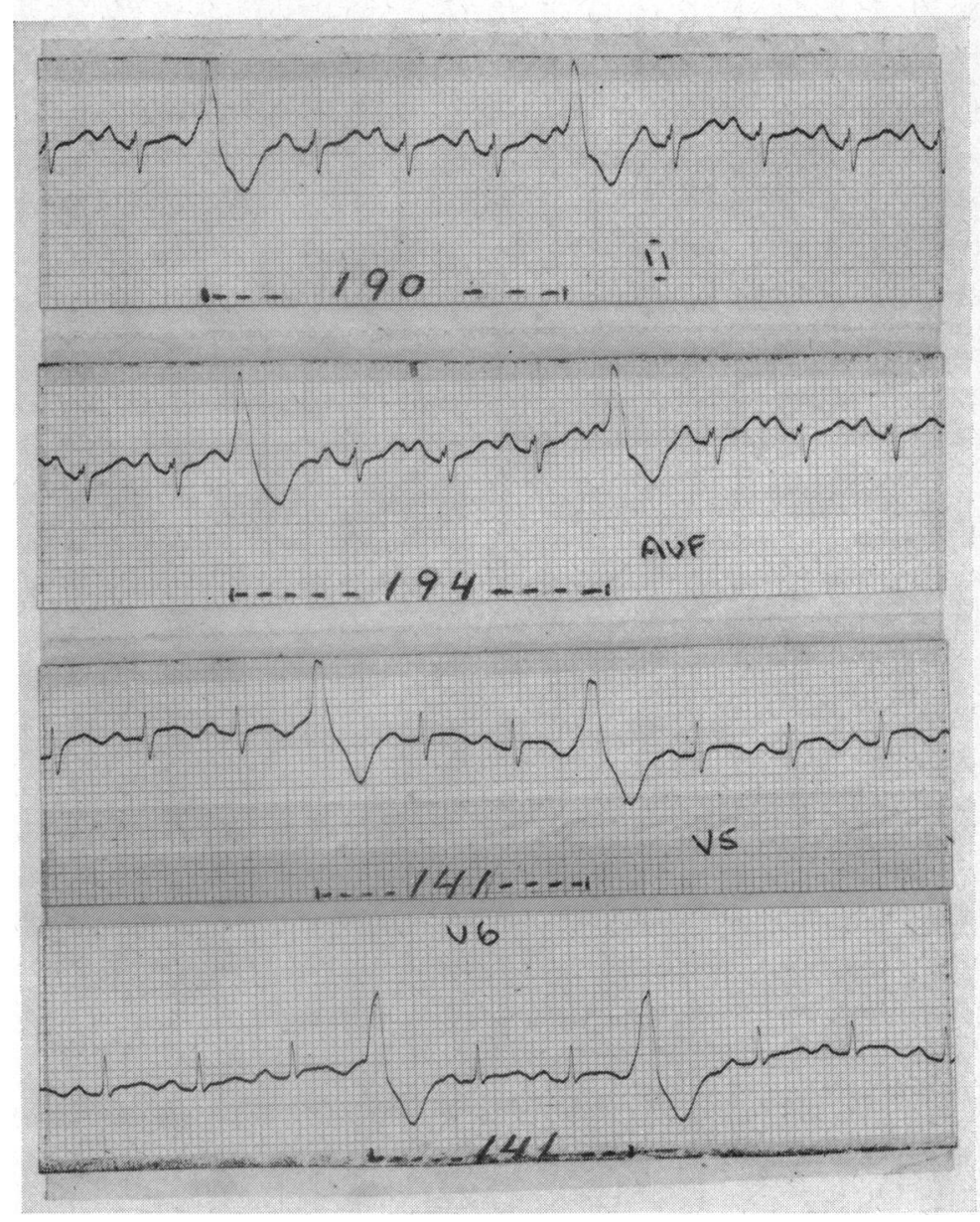

FIG. 2 Case 2. Delay of parasystolic beats

(leads II and aVF) (see text).

in $I$ in Io days. The patient with the longest duration of parasystolic focus (Case 5) received digitalis before the appearance of the arrhythmia, and it is possible in this patient that digitalis in some way played a part in the production of the ventricular parasystolic focus.

Most of the patients had fever, and triple rhythm associated with crepitation in the lungs, regarded as evidence of left ventricular failure. It is not surprising, therefore, that in 7 patients sinus tachycardia was present before the appearance of ventricular parasystole. One (Case 7) had sinus bradycardia. Another (Case I) had a transient episode of fibrillation; ventricular parasystole has been described in atrial fibrillation (Scherf and Schott, 1951), but in our patient the ventricular parasystolic focus was controlled 12 hours before the appearance of atrial fibrillation; on the other hand, atrial fibrillation is the second most frequent arrhythmia after 


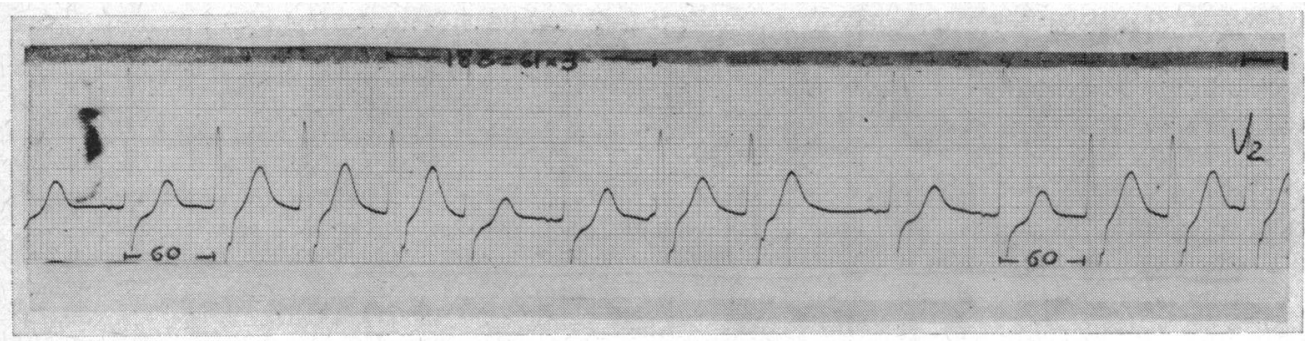

FIG. 3 Case 3. Intermittent parasystole. The first parasystolic beat is always coupled to the preceding sinus beat (complex 2 and II). After a few beats, the parasystolic focus is blocked, and appears again later (complex II).

FIG. 4 Case 5. Intermittent parasystole. The first parasystolic beat is coupled to the preceding sinus beat. The interectopic interval is a multiple of the ectopic cycle. The parasystolic focus only becomes manifest during the supernormal phase of excitability for a few beats and is then blocked.

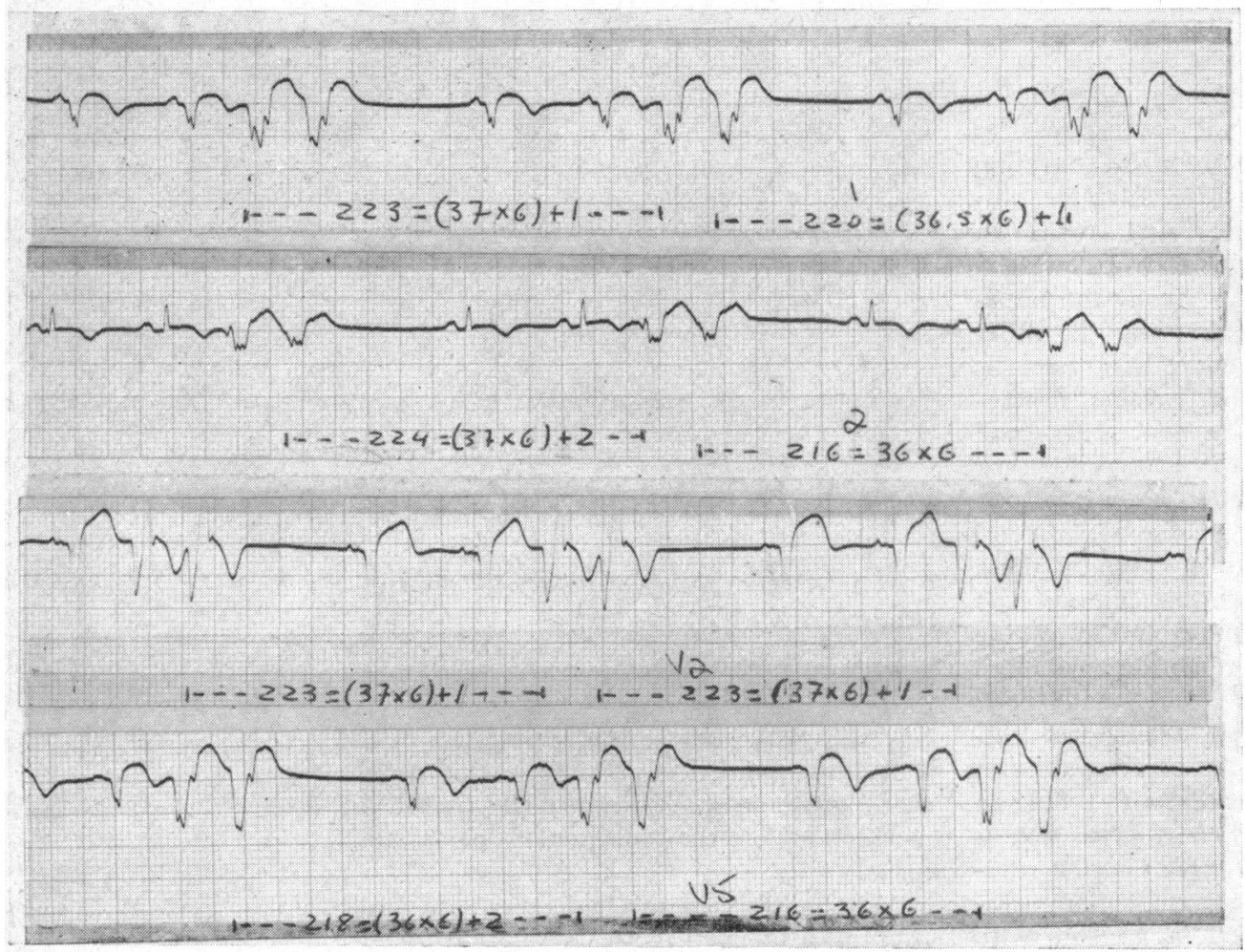

premature contraction in acute myocardial infarction (Friedberg, 1966), and the finding of atrial fibrillation in this patient is not surprising and is unlikely to be related to ventricular parasystole.

It is generally accepted that low serum potassium levels predispose to ectopic beats; in these conditions, the resting membrane potential is augmented, and the duration of the action potential is increased because of the lengthening of phase 3 ; phase 2 is shortened (Friedberg, 1966). Only one patient
(Case 3) had low plasma potassium levels, and remained with abnormally low levels after the disappearance of ventricular parasystole; the other Io patients had normal levels of plasma potassium. It seems that there is no relation between ventricular parasystole in acute myocardial infarction and plasma potassium levels.

We also tried to find out if there was any relation between ventricular parasystole and the amount of myocardium damaged, assuming there is a relation between the serum 
aspartate aminotransferase (SGOT) values and the extent of the infarct. A linear correlation has been shown between SGOT peak levels and the amount of tissue damaged after experimental coronary occlusion and myocardial infarction in dogs; serial SGOT determinations were done (Agress et al., 1955). This correlation has not been found in clinical practice due in part to failure to obtain true peak serum enzyme values because of insufficient determinations, or, alternately, disproportionately high values are obtained because the enzyme is supplied to the serum by other damaged tissues (Friedberg, 1966). In our series, the higher serum values of SGOT varied widely, from 510 units/100 ml. in Case $\mathrm{I}$, to 80 units/100 $\mathrm{ml}$. in Case 4.

The artificial pacemaker has been compared to a physiological ventricular parasystolic focus (Burchell, 1963). In studies with surgically implanted myocardial pacemakers, the impulse from the pacemaker began to produce a response just after the peak of the $T$ wave. Studies in 2 patients with an implanted pacemaker showed that the supernormal period started at about the middle of the terminal slope of the $T$ wave and ended shortly beyond the peak of the $U$ wave (Walker, 1966). The shorter coupling of the parasystolic focus in this series always corresponds to this supernormal period of excitability. No one case had a coupling in the relative refractory period.

Retrograde conduction of the parasystolic beat to the atria has been shown by the occurrence of sharply inverted $\mathbf{P}$ waves after the parasystolic beat (Scherf and Schott, 1953), and a ventricular echo initiated by a parasystolic beat (Pick, 1953). No evidence of retrograde activation of the atria was seen after artificially induced parasystole in man produced by a surgically implanted pacemaker (Nuñez-Dey, Zalter, and Eisenberg, 1962). In Case 5 (Fig. 4) retrograde conduction occurred and temporarily depressed the discharge rate of the sinus node (concealed conduction).

The interectopic interval was always exactly or a very close multiple of the ectopic cycle length in all the cases in which this ectopic cycle length was seen. Regularity of discharge of the ectopic pacemaker is the accepted cardinal sign of parasystole. But the abnormal parasystolic focus may work arrhythmically owing to a change of nerve tonus or conduction delay from their focus to the ventricles (Scherf and Boyd, I950; Pick, 1953), or because of a temporary release of an exit block which had kept many impulses con-

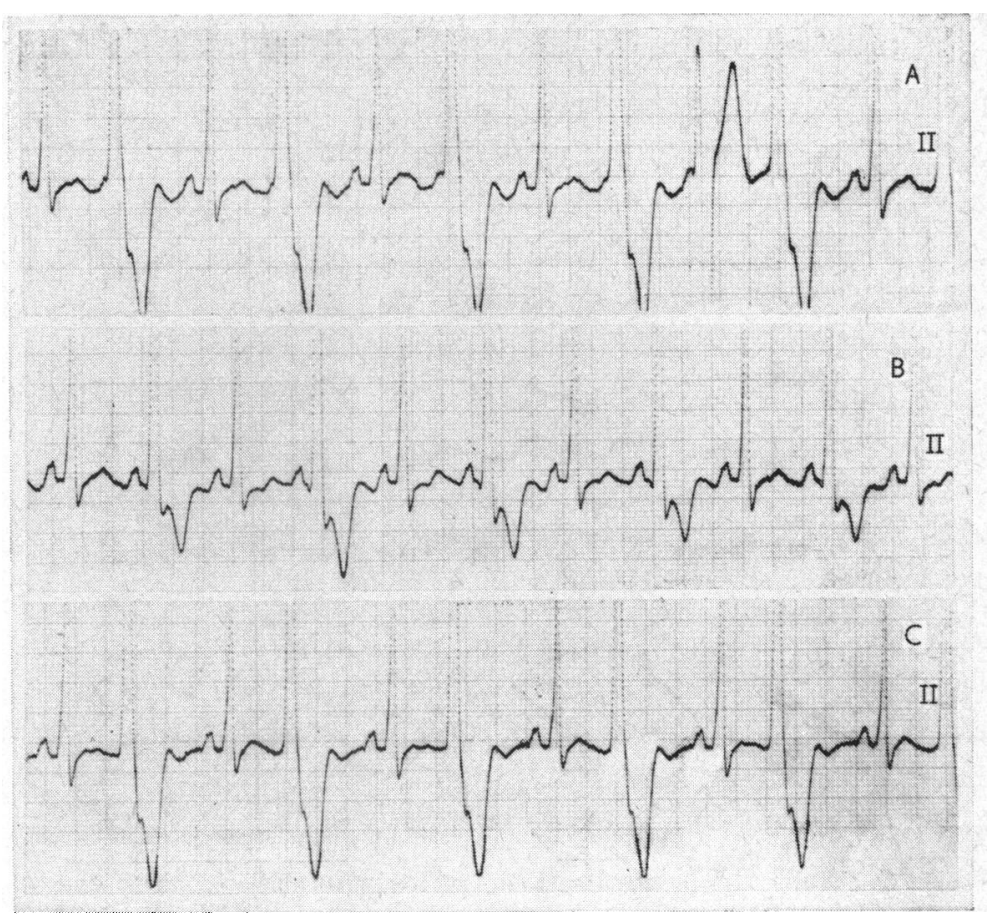

FIG. 5 Case 9. (A) Parasystolic focus

firing at I10 a minute, with $2: 1$ exit block.

The exit block suddenly disappears at the end of the strip. (B) Different degrees of fusion beats. (C) The appearance of bigeminy caused by a mathematical relation between the sinus rate and the ectopic discharge rate.

fined exclusively to the immediate region of the parasystolic pacemaker (Pick, 1953). In Case 2 (Fig. 2), there is no manifest ectopic cycle length. The shorter interectopic interval is always about $I \cdot 40$ sec., and the longest interectopic interval is a close multiple of this. But sometimes an interectopic interval is longer than 1.40 sec., and not a multiple of this (leads II and aVF); in those interectopic intervals, the $P$ wave precedes the second parasystolic beat at $0.56 \mathrm{sec}$. It is possible that this parasystolic focus is firing with a 2:I exit block, and sometimes the normal stimulus spreading over the heart breaks into the ectopic centre during its supernormal phase of excitability (this temporarily abolishes the 'protective block'), delaying its stimulus formation for a few hundredths of a second (Scherf and Chick, 195I; Pick, 1953); this would explain the close correlation between the second ectopic beat in this interectopic interval and the preceding $P$ wave.

The transition from parasystole into an extrasystolic arrhythmia has been seen on 


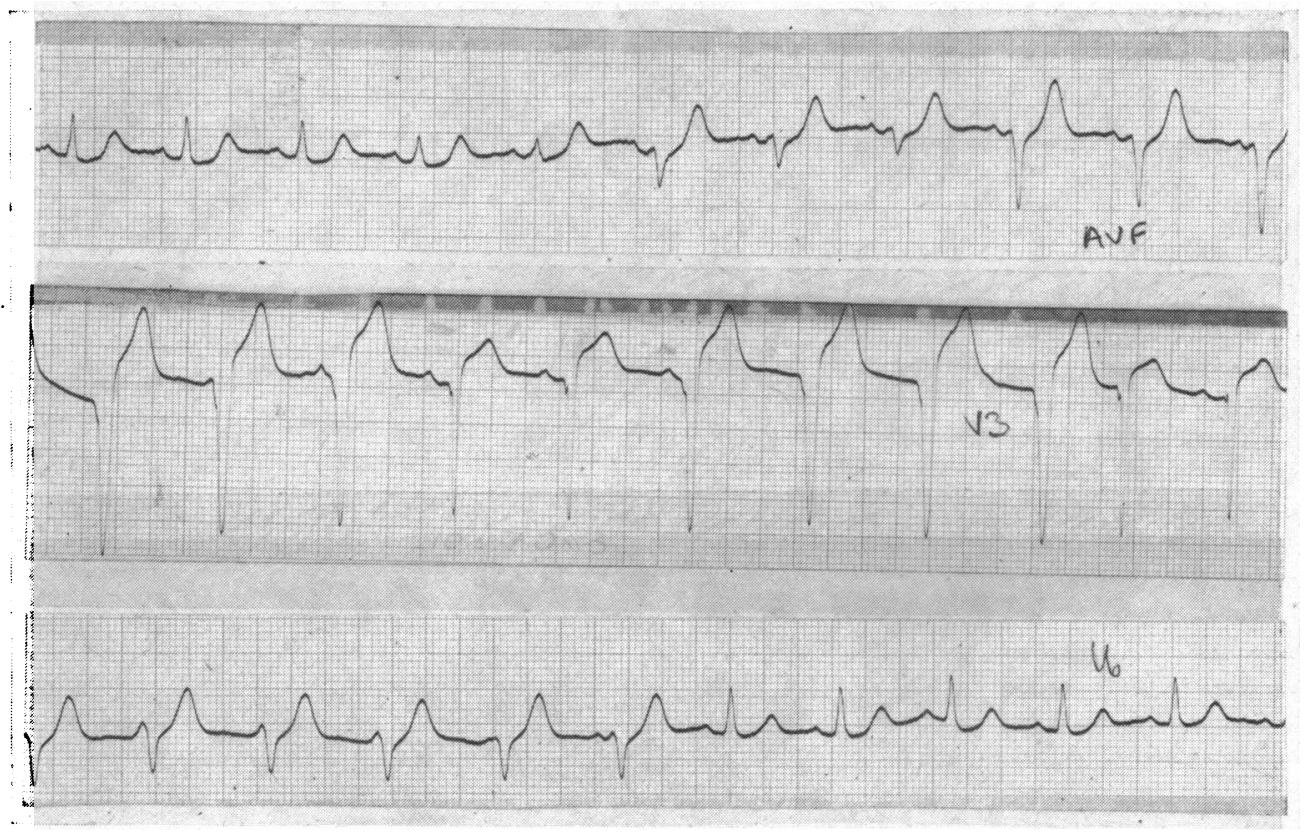

FIG. 6 Case II. The discharge rate of the sinus node (90/min.) and the parasystolic focus (86/min.) are very close; a long period of one rhythm alternates with a long period of the other.

rare occasions (Scherf and Schott, 1953; Schamroth and Marriott, 1963; Vedoya and Rodriguez Battini, 1939). The development of both an automatic (parasystolic) and a forced (extrasystolic) discharge from the same focus suggests that the extrasystole represents a forcing or premature precipitation of the parasystolic discharge by the sinus impulse (Schamroth and Marriott, 1963). None of our patients has had this transition from parasystolic to extrasystolic arrhythmia. In 2 patients (Case I, Fig. I, and Case 9, Fig. 5) an intermittent trigeminy and bigeminy respectively appear, but this is only a coincidence, and is produced by a simple mathematical relation between the discharge rate of the sinus node and the parasystolic focus (Langendorf and Pick, 1955).

There are two classical forms of parasystole: (a) parasystole with simple interference (the rate of the parasystolic focus is lower than that of the sinus node), and (b) parasystole with exit block (the rate of the parasystolic focus is faster than that of the sinus node, and some of the ectopic impulses are prevented from becoming effective by a mechanism termed exit block (Scherf and Schott, 1953; Rossi et al., 1959)). In this series, 6 patients (Cases 4, 6, 7,8, I0, and I I (Fig. 6)) had parasystole with simple interference, and the other 5 (Fig. I, 2, 3, 4, and
5) parasystole with exit block. Some of the patients in the first group (Table 2) had a slightly faster rate of parasystolic focus than that of the sinus node; in this situation, parasystole with simple interference is possible only if the difference in rates is very small, since otherwise ectopic rhythms would appear (Scherf and Schott, 1953). In the group of 5 patients with parasystole with exit block, there were 2 with intermittent parasystole (Cases 3 and 5). In intermittent parasystole, the first parasystolic beat is always coupled to the preceding sinus beat, and rhythmic ectopic stimuli stop after a few beats (Scherf and Boyd, 1950). In Case 3 (Fig. 3), the first parasystolic beat appeared late in diastole, when the next sinus beat was due; then the ectopic centre temporarily experienced a change of excitability so that it was not affected by sinus stimuli; it became protectively blocked and this led to an independent stimulus formation in this centre. Why it is that extrasystoles appearing only very late in diastole induce this mechanism is difficult to explain (Scherf and Boyd, 1950). In Case 5 (Fig. 4), the first parasystolic beat always appeared during the supernormal phase of excitability of the preceding sinus beat, and after a few beats it was blocked; this was probably because the stimuli from the ectopic centre were not strong enough to spread 
over the ventricles unless a stimulus emerged during this supernormal phase of the preceding sinus beat (Mueller and Baron, 1953).

Most of the cases of ventricular parasystole reported had fast ectopic discharge rates, with more or less severe exit block. In 9 of our patients in whom there was an ectopic cycle length (Fig. I, 3, 4, 5, and 6), the ectopic discharge rate was faster than 1 Io beats a minute in 5 of them (Fig. I, 3, 4, and 5), and we have no way of knowing whether the other slower manifest ectopic discharge rates were not the expression of a $2:$ I or 3: I exit block. Slowing of the parasystolic centre by carotid sinus pressure has been shown (Golbey et al., 1954). All these observations indicate that the parasystolic centre differs from the physiological deeper ventricular centres, with a slow rate, and without response to carotid sinus pressure. An abnormal, rapid kind of impulse formation seems more probable (Scherf and Bornemann, I96I).

The arrhythmia was easily controlled with treatment, and all the patients recovered normally. We conclude, therefore, that this is a benign arrhythmia, produced perhaps by the same mechanisms as ventricular tachycardia, but fortunately with some degree of exit block. The possibility of transformation of this parasystolic arrhythmia into an extrasystolic arrhythmia appears unlikely.

\section{References}

Agress, C. M., Jacobs, H. I., Glassner, H. F., Lederer, M. A., Clark, W. G., Wroblewski, F., Karmen, A., and LaDue, J. S. (I955). Serum transaminase levels in experimental myocardial infarction. Circulation, 1I, 7II.

Burchell, H. B. (1963). Analogy of electronic pacemaker and ventricular parasystole with observations on refractory period, super-normal phase, and synchronization. Circulation, 27, 878.

Chung, K. Y., Walsh, T. J., and Massie, E. (1964). Double ventricular parasystole. American Heart Fournal, 67, 162.

East, T., and Bain, C. (1959). Recent Advances in Cardiology, 5th ed. Churchill, London.

Friedberg, C. K. (1966). Diseases of the Heart, 3rd ed., pp. 811,845 , and 1654. Saunders, Philadelphia and London.

Golbey, M., Ladopulos, C. P., Roth, F. H., and Scherf, D. (1954). Changes of ventricular impulse formation during carotid pressure in man. Circulation, ro, 735 .

Heinz, R. E., and Eldridge, F. L. (1957). Ventricular parasystole in a five-year-old child. American Heart fournal, 53, 624 .
Katz, L. N. (1946). Electrocardiography, 2nd ed. Lea and Febiger, Philadelphia.

, and Pick, A. (1956). Clinical Electrocardiography. Part I. The Arrhythmias. Lea and Febiger, Philadelphia.

Kistin, A. D. (1966). Ventricular tachycardia and esophageal leads. In Mechanisms and Therapy of Cardiac Arrhythmias, 14th Hahnemann Symposium, p. 279. Ed. by L. S. Dreifus and W. Likoff. Grune and Stratton, New York.

Langendorf, R., and Pick, A. (1955). Mechanisms of intermittent ventricular bigeminy. II. Parasystole, and parasystole or re-entry with conduction disturbance. Circulation, II, 431.

Malinow, M. R., and Langendorf, R. (1948). Different mechanisms of fusion beats. American Heart fournal, 35, 448 .

Marriott, H. J. L., Schwartz, N. L., and Bix, H. H. (1962). Ventricular fusion beats. Circulation, 26, 880.

Mueller, P., and Baron, B. (1953). Clinical studies on parasystole. American Heart fournal, 45, 44I.

Nuñez-Dey, D., Zalter, R., and Eisenberg, H. (1962). Artificially induced parasystole in man due to surgically implanted myocardial pacemaker. American fournal of Cardiology, 10, 535.

Pick, A. (1953). Parasystole. Circulation, 8, 243.

Rossi, P., Motolese, M., and Passaro, G. (1959). Idioventricular parasystole with exit block in a subject with complete atrioventricular dissociation. American Heart fournal, 57, 775.

Schamroth, L. (1962). Ventricular parasystole with slow manifest ectopic discharge. British Heart fournal, 24, 731.

- and Marriott, H. J. L. (1963). Concealed ventricular extrasystoles. Circulation, 27, 1043.

Scherf, D., Blumenfeld, S., and Yildiz, M. (1962). Extrasystoles and parasystole. American Heart fournal, 64, 357.

- and Bornemann, C. (1961). Parasystole with a rapid ventricular center. American Heart fournal, 62, 320.

-, and Boyd, L. J. (1950). Three unusual cases of parasystole. American Heart fournal, 39, 650.

$\longrightarrow$, and Chick, F. B. (I95I). Experimental parasystole. American Heart fournal, 42, 212.

$\longrightarrow$, and Schott, A. (195I). Coupled extrasystoles and automatic ventricular rhythms. American Heart fournal, 41, 291.

$\longrightarrow$, and - (1953). Extrasystoles and Allied Arrhythmias, pp. 156, 158, 160, 176, 191, and 520. Heinemann, London.

Surawicz, B., and MacDonald, M. G. (1964). Ventricular ectopic beats with fixed and variable coupling. American fournal of Cardiology, $13,198$.

Vedoya, R., and Rodriguez Battini, A. (1939). Un caso de pararritmia mostrando el mecanismo que conduce al bigeminismo extrasistolico. Revista Argentina de Cardiologia, 6, 313.

Walker, W. J. (1966). Factors affecting the supernormal period and threshold of the ventricle. In Mechanisms and Therapy of Cardiac Arrhythmias, I4th Hahnemann Symposium, p. 252. Ed. by L. S. Dreifus and W. Likoff. Grune and Stratton, New York. 